\title{
The Pragmatist Approach to Sociocultural Transformation as an Alternative to Neoliberal Radicalism
}

\author{
L'ubomír Dunaj \\ University of Prešov, SK
}

\begin{abstract}
DUNAJ, L.: The Pragmatist Approach to Sociocultural Transformation as an Alternative to Neoliberal Radicalism. Philosophica Critica, vol. 1, 2015, no. 2, ISSN 1339-8970, pp. 19-31

This paper focuses on the pragmatist approach to sociocultural transformation and suggests its useful potential for current issues in the Central European post-socialist reality. The exposition consists of three parts: first, it elucidates the super-civilizational radicalism of neoliberalism, which dominated during the last two decades the public discourse in V4-Countries (I.). Secondly, it investigates the conception of a transformative approach to social reality in opposition to a revolutionary one (II.). Finally, it offers a pragmatist reflection on the sociocultural transformation and the task of social critics as an adequate approach for a successful transformation (III.).
\end{abstract}

Key words: Pragmatism - Transformation - Neoliberalism Change - Critique

Emil Višňovský ${ }^{1}$ introduces his reflections regarding the pragmatist understandding of sociocultural transformation, in his book New Studies about Pragmatism and Neopragmatism (In Slovak; Višňovský 2014a), with the question "How much transformation is a man able to manage?" (analogical to Rüdiger Safranski's question, "How much globalization is a man able to manage?"). Višňovský states that "a social transformation is sometimes a quite painful, even impairing process. Each social transformation includes certain 'costs and yields' of people, probably

1 Emil Višňovský is a professor of philosophy at the Comenius University in Bratislava (Department of Philosophy and History of Philosophy), vice president of Slovak Academy of Sciences, as well as co-chair of Central European Pragmatist Forum. 
also victims, and it is impossible to count up and to number every one of them. Too much transformation can do us harm, if we are not ready for it" (Višňovský 2014a, 102). Therefore, the first step of my paper is directed at Johann P. Arnason's commentary on Jan Patočka's text from 1950s Superci-vilization ${ }^{2}$ and its inner conflict (Patočka 1996), in which he shows the metamorphoses of radicalism in the modern age (Arnason 2010). According to Arnason, Patočka's originality - from the contemporary perspective - consists in the point that he was the first who saw modernity as a civilizational paradox: "It is something more and simultaneously something less than traditional civilization. This paradox is adopted and stabilized by a moderate supercivilization (however it does not explain that paradox always in the same way and also not with the same adequacy). On the other hand, the radical variant of supercivilization strives to overcome that paradox by using more militant explanation of modern principles" (Arnason 2010, 16).

\section{“Quasi” rational radicalism of neoliberalism (in Slovak educational system)}

Arnason claims that the most explicit definition of supercivilizational radicalism emphasizes its radical effort and aspiration to make rationality the key to answerring every question in life. "Communism belongs to the history of supercivilizational radicalism, and doubtless, Patočka's whole concept originates primarily as an attempt to understand and classify communist phenomena; nevertheless, a radical supercivilization is not identical only with communism, and it does not follow from Patočka's argumentation that communism necessarily represents its definitive or the last possible form. Rather, at the beginning of the $21^{\text {st }}$ century, the hypothesis is made that the ideological amalgam of market fundamentalism (which combines many resources, which do not have to belong solely into the category of radicalism per se) was established as a new form of supercivilizational radicalism. It continues - albeit in a very selective way - the heritage of classical utilitarism" (Arnason 2010, 44).

Although we are lacking a detailed analysis of Slovak society as a whole, a very good example, in which such processes of 'rational' radicalisation could be observed, offers, for instance, the Slovak educational system. ${ }^{3}$ In the introduction to the collective volume University, Society, Philosophy: the Reality vs. Values (in Slovak), its editor Emil Višňovský identifies crucial factors, which jointly determine the

\footnotetext{
2 In Patočka's vocabulary the term 'supercivilization' means modernity.

3 I pointed out the Slovak educational system, since this paper was presented at the conference 'PRAGMATISM and EDUCATION in the Visegrad Countries: History and Vistas', which took place at the Masaryk University in Brno (Czech Republic) on May 7-9 2015.
} 
current situation in Slovak academic sphere such as globalization and crisis, neoliberalism and academic capitalism, corporatization and managerism, marketization and commodification, economization and bureaucratization. The consequences of those trends, as Višňovský notes in connection to K. P. Liesmann's book Theory of illiterateness. Mistakes of the knowledge society 4 (in German), implies "a loss of academic autonomy and a jeopardy for academic freedom, a change of character of academic work and a ricketiness of the academic identity of scientist and university professors" (Višňovský 2014b, 8). ${ }^{5}$

In the very same book, Miroslav Tížik ${ }^{6}$ focuses on various forms of discourse about the academic world and scientific policy of Slovakia and calls our attention to the way in which particular agents are able to influence or offer an answer to the question, "What is the importance and value of science for a society?" (Tížik 2014,168 ) He mentions the predominance and growing importance of neoliberal discourse - for example regarding proposals promoting the inevitability of changes in a public institution such as the Slovak Academy of Sciences - as an illustration of that very problem. Such discourse, whose central concepts include necessity, efficiency, and flexibility, serve to over-simplify complex social relations and indirectly justify the precarization of labour in the Slovak Academy of Sciences (Tížik 2014, 171). As Tížik interestingly remarks, the audit culture in Slovakia (originally coming from Great Britain) manifests itself in some cases as a kind of parody rather than as a serious attempt at policy change. To take just one example, the Academic Ranking and Rating Agency (ARRA) ${ }^{7}$ rated the Faculty of Humanities at the technically oriented University of Žilina as having the best faculty of humanities in Slovakia in the year 2013 - even though it is virtually unknown in the social sciences and humanities. That faculty even does not have a department of philosophy, but has a department of mathematics, which is not usual in philosophical faculties and faculties of humanities.

Peter Sýkora ${ }^{8}$ focuses on the current system of evaluation and financing of scientific research activities on the Slovak public universities. It is a testimony of how absurd the evaluating procedure of academic work in Slovakia actually is. First of all, Sýkora criticises the focus of the Ministry of Education of the Slovak Republic by evaluation and financing Slovak public universities only on the scientific research activity and only on quantitative parameters especially the number of scientific publications. Then he points out that the current setting of the

\footnotetext{
4 (Liessmann 2006).

5 See also (Hvorecký 2015).

6 Miroslav Tížik is a senior research fellow at the Institute of Sociology, Slovak Academy of Sciences and active public intellectual.

7 http://www.arra.sk/english

8 Peter Sýkora is a professor of philosophy at the University of St. Cyril and Methodius in Trnava, Slovak Republic.
} 
evaluation of higher education does not lead to an increase in quality, but rather "develops enormous pressure on universities in order to steadily decrease their scientific and educational quality" (Sýkora 2014, 91). It has to mention at least one of the many absurdities contained in the assessment methodology of research work, where the author states that the "shockingly lowest weight between 0,044 scientific publications have chapters according to the methodology of international and scientific monographs (ABC, $A B D$ ). In practice, this means that a university gains from the Ministry of Education's budget ten times less finances for a chapter in a scientific monograph prepared by prestigious international teams of the world's top scientists than the contribution in a vocational, i.e. non-scientific collective volume published by a domestic publisher" (Sýkora 2014, 108-109). This has a dramatic impact especially for the humanities, because the chapters in scientific monographs along with the monographs are the most prized publicatio output. Probably this is one of the most important reasons, why there are so few Slovak humanities scholars who could be intensively involved in any foreign discussion dedicated to a particular problem. Therefore, they are not corresponddingly known and recognized in the academic community abroad (by which I do not mean the Czech Republic).

As the result, it is appropriate to employ the term 'quasi rational' to describe the radicalism of these neoliberal reforms and evaluations, precisely because their character and consequences clearly exhibit deficits in rationality. Therefore, it is important to stop, or at least reduce neoliberal and technocratic approaches to the evaluation, governing and controlling of different (especially public) spheres of social life. The reference to conceptions like "rational" or "reasonable" transformation of our society, is seldomly a "great leap forward". However, many Slovak politicians and economists don't see - because of their infatuation with neoliberal beliefs - how narrow-minded and superficial their suggestions are.

\section{Three approaches to a moderate understanding of social changes}

The perspective, from which this paper is presenting a successful social transformation by moderate changes, is consistent with the view of Jan Patočka. For further development of his ideas I found inspiration in three different philosophical schools or traditions.

The first is the concept of 'silent transformations' inspired by the Chinese philosophical tradition - originating in the Book of Changes - which has been the focus of the work of the French philosopher and sinologist François Jullien (Jullien 2011). The second source is Critical Social Theory (so called Frankfurt School), especially the works of Axel Honneth and his work on recognition and social freedom. The third is, the philosophy of Pragmatism (in J. Dewey's version). 
While I recognize that this connection might seem artificial on its face and, therefore, would require a much deeper elaboration than I am able to offer in this paper, my aim is simply to indicate some possible connections between European, American and Chinese philosophy as the three most influential cultural focal points. It can help us to successfully deal with the demands of a globalized world and thereby provide a fruitful basis for reflection on educational reform (not just) in the Slovak Republic or in the Visegrad Countries Region. Indeed, the demand of minimal ethical universalism, of a specific kind of "global" morality, is increasingly becoming a pressing concern in light of the increase of global interactions, characteristic for the economic globalization, which requires stronger regulation. These regulations and the new global ethics, however, should not be established as merely the consequence of the preferences or dictates of (Western) world powers, but rather as a result of an intercultural dialogue. Only a proper dialogue between cultures and civilizations is able to enable us to establish the requisite baseline of ethical standards to avoid future crises. The leaders of educational systems in the V4-countries, therefore, have to consider the current global reality and seek to integrate and implement relevant ideas from other cultures.

Why to choose a concept from non-western culture, which has in fact not so much to do with a democratic tradition, and which in Jullien's interpretation contains a very cardinal controversy? ${ }^{9}$ At this point, since I am not going to discuss his conception in depth, I have to emphasize a very general statement, that the regimes, which existed in Central and Eastern Europe in the late eighties of the twentieth Century, needed reforms, especially of a democratic type. These regimes, however, at least in Central Europe (Poland, Hungary, Czechoslovakia), were not totalitarian in nature. They were indeed strongly authoritarian, but not totalitarian, like it is mostly interpreted in the West, which means that they were (presumably) able to reform themselves. ${ }^{10}$ The people really wanted freedom and

\footnotetext{
${ }^{9}$ In the last chapter Jullien namely says that: "The myth of humans as being able to chooseact is necessary to democracy, and is thus salutary to preserve, but it cannot hide what it detaches itself from: it could not conceal the importance of what is neither the weight of structures nor anonymous forces, that have traditionally been opposed to it, but these general orientations and discreet propensities ( $d a$ shi, the Chinese say) inflecting their epoch" (Jullien 2009, 144-145). Jullien makes such impression as if those "general orienttations" and "discreet propensities" were something "automatic", without concrete selfconscious decisions of people. It is false and it can be demonstrated by appealing for example to cultural studies, which represent a reflexive and creative diversity passing through our everyday practice, thereby underlining the presence of resistant and nonconformist attitudes even in the most standardized "entertainment goods" (Kögler 2006, 55). So Kögler problematizes Jullien's unappreciation of “homo agens” (Višnovský 2009).

10 Compare (Novosád 2004; Dinuš 2010).
} 
democracy, ${ }^{11}$ but now we can see, what in 1989 was not so clear, namely that there are many interpretations of freedom and democracy. And today, since the neoliberal interpretation of freedom dominates, most of our population is really disappointed because of the transformation after 1989.12 To go on, we can say, that it is a historical catastrophe for Central and Eastern Europe that the collapse of socialist regimes corresponds with the neoliberal wave in the West. ${ }^{13}$ We can put the beginning of this neoliberal wave at Reagan's and Thatcher's reforms in the eighties and can put the end, at least I hope, to the year 2008, when the economic crises showed, that the neoliberal way of economy is a very problematic one.

Today many people consider the situation in Slovakia in many areas critically, because of a huge unemployment, pauperisation of big parts of inhabitants, rise of slums, where mostly Roma (Gypsies) live, but also of other poor people. There are many other fatal problems, like collapse of our agriculture industry or mastery of political power by oligarchs. The transformation from the Soviet-type economic to a capitalistic one had the worst and very often also bloody phase in 1990 - 2000. I have to mention, that in countries like Yugoslavia, Romania, Bulgaria and Russia it was much more dramatic than in Central Europe. And in the Ukraine, where this transformation is by now, hopefully, in the last phase today although, of course, in the Ukraine there are also other factors. These facts are the reasons, why many thinkers are curious (for instance Marek Hrubec ${ }^{14}$ ), how China, in comparison to Eastern Europe, was able to manage through such a huge and successful transformation after 1978 and especially 1989, although behind their success Jullien sees the understanding of social processes as permanent silent transformations. ${ }^{15}$ Closer elaboration goes beyond scope of my paper, but I believe, it can offer many productive impulses.

Axel Honneth's interpretation of the legacy of Critical Theory, in which he discusses the difference between Critical Theory, liberalism and communitarism, is for me the second point of departure. According to him, the Hegelian idea of the rationality of cooperative self-actualisation, which all members of critical theory share and which is critical to liberalism and communitarism (in Patočka's vocabulary we could use in some aspects word conservativism), is significant for a critical social theory. All concepts of a rational practice, which are applied by Critical Theory, are suitable for the procedure, whose achievement demands a higher

\footnotetext{
11 (Krapfl 2013).

12 (Dinuš 2015, 209).

13 I thank Johann P. Arnason for this formulation.

14 Marek Hrubec is head of the Centre of Global Studies at the Institute of Philosophy at the Academy of Sciences of the Czech Republic.

15 Of course, also the Chinese transformation is not absolutely unproblematic. Compare for instance (Roetz 2011).
} 
degree of the intersubjective agreement than is acceptable for liberalism: 16 "to be able to cooperate on an equal basis, to interact aesthetically, and to reach agreements in a noncoerced manner, a shared conviction is required that each of these activities is of an importance that justifies, if necessary, the neglect of individual interests" (Honneth 2009, 27). ${ }^{17}$ On the other hand "no critical theorist has ever abandoned the Hegelian idea that cooperative practice, along with the values attendant to it, must possess a rational 18 character" (Honneth 2009, 28). A transition to liberating practises of cooperation should not result from an affective bond, or from a feeling of affiliation or approval, but from rational perspective. ${ }^{19}$ So, "the tradition of Critical Theory thus differs from both liberalism and communitarianism by virtue of a particular kind of ethical perfectionism. To be sure, unlike the liberal tradition, Critical Theory holds that the normative aim of society should consist in reciprocally making self-actualization possible. At the same time, it understands its recommendation of this aim to be the well-grounded

16 See why A. Honneth is not a liberal: (Deranty 2009, 394-404).

17 At this point Honneth stresses similarities between Frankfurt school Critical Social Theory and Pragmatism, and refers to Hans Joas (Joas 1993).

18 I quote two passages from J. P. Deranty's book Beyond Communication for better understanding of Honneth's interpretation of rationality: "Hegelian reason, on that account, is seen as having an essentially Kantian character, insisting as it does on the normative and self-legislating aspects of rationality. From such a perspective, the main correction that is brought by Hegel to the basic Kantian image of self-determining rationality and freedom, is the element of sociality, as self-legislation is for Hegel the product of a whole social world reflecting on what counts for it as basic ground for belief and action. The emphasis on "the sociality of reason, however, does not lead to a sociological or cultural-relativist dissolution of the rational content of normative and cognitive claims. Rather, what counts in the definition of the norms is not just the self-reflection of the social world on its concrete existing practices, but rather the normative moment of justification, in terms of "reasongiving", by that social world, of its own norms. The norms are indeed historically produced, but they must be able to be justified in practices of normative self-clarification: not every institution and practice can pass the test of "giving and accepting reasons". The focus on the normative and the intersubjective makes this new vision of Hegelian Sittlichkeit appear very close to Habermas' and Honneth's own vision of modern societies. Indeed, the mechanism of "reason-giving", seen as the core mechanism explainning normative integration, seems very close to Habermas' emphasis on the redeemability of validity claims as the core normative process in action coordination. Equally, one of the key dimensions in these non-metaphysical readings of Hegel is the necessity of "mutual recognition" to account for social reproduction: if reason for Hegel is nothing substantive or metaphysical, but rather the self-legislating practice of a whole polity reflectively attempting to justify its own norms, then mutual recognition is a necessary prerequisite" (Deranty 2009, 206, 207).

${ }^{19}$ See why Honneth is not a communitarian (Deranty 2009, 383-393). 
result of a certain analysis of the human process of development" (Honneth 2009, 28).

Patočka's rejection of communist radicalism and the broad critique of neoliberalism by many contemporary philosophers and social scientists goes very well together not only with similar remarks by John Dewey, ${ }^{20}$ and Honneth's interpretation of the legacy of Critical Theory, but also with Emil Višňovskýs enlisttment of pragmatism to find a middle position between liberalism and Marxism.

According to Višňovský, "the 'middle position' of pragmatism in political theory and praxis" means that "pragmatism is neither in sharp ideological opposition to liberalism nor to Marxism. On the contrary, it finds in both a 'rational core' and aspects, with which pragmatism sympathizes. The philosophical framework and the basis of such ideological integration is represented by pragmatistic antidualism, i.e. the negotiation of traditional oppositions between individual and community, individualism and holism, nature and culture, subjective and objective, facts and values, aims and means, morality and politics, politics and economics, right and left, capitalism and communism, ideals and reality, motives and deeds, etc., namely those, what liberalism and Marxism traditionally sepa-rates and juxtaposes" (Višňovský 2014a, 119).

\section{An adequate form of critique as important aspect of successful transformation}

The last part of my paper is based on Višnovský's sketch of pragmatistic reflection of sociocultural transformation and on Axel Honneth's thinking about the task of social critics. The success of a concrete society depends on its ability to adequately change its principles in case they become obsolete, which in turn, enables it to minimize social upheavals and avoid negative scenarios.

According to Višňovský, pragmatism rejects the existence of eternal, invariable, constant, ideal platonic "forms" or universal essences of all variable individual things: "Forms are rather real than ideal, for things are inherent, they are mutual, in progress, i.e., they transform themselves, together with things and in their context" (Višňovský 2014, 105).

As Višňovský states, we can even say that the whole "spirit" of American philosophy and especially pragmatism is transformative, in the sense of vision, revision, imagination and creation of our understanding of the world. There are some additional important features of pragmatism, which Višňovský discusses, for

20 In his world famous book from 1939 Freedom and Culture - especially in chapter 'Totalitarian Economics and Democracy' (Dewey 1988, 116-135). 
example: the conception of anti-finitism, perishableness, extempo-raneousness, continuity and temporality, dynamism, processuality and anti-absolutism. With regards to ontology, there is the priority of time and change, potentiality, and contingency over immutability/permanence - nothing is given to us as fixed and absolute, which we cannot create and transform by our activity. For the aims of the paper, it is important to stress the orientation of pragmatism towards praxis and action. Human activity per se means transformation - through an active contribution and intervention into reality, through experimenttation and reconstitution of various situations (Višňovský 2014, 107). It does not, however, represent a defence of a blind, anarchistic or arbitrary transformation at all costs, but rather a directed, conduced, controlled, planned, "humanistic" transformation in the name of human well being (Višňovský 2014, 108). And it is at this very point that social critique has an important role to play - indeed as Višňovský points out, social and cultural critique, as an instrument of pragmatism for transformation, represents an essential characteristic of pragmatist philosophy as well. At this point I consider the tie up with Axel Honneth as productive again- as an eventual way to the adequate and efficient social critique -, whose works are very strongly influenced exactly by pragmatism (especially G. H. Mead and J. Dewey ${ }^{21}$ ) and his thoughts about task of social critics.

In his study Idiosyncrasy as a Tool of Knowledge. Social Criticism in the Age of the Normalized Intellectual Axel Honneth considers whether the present-day normalized intellectual, "a spiritual agent in the fora of public opinion formation", is "really the natural representative today, of what was once called 'social criticism"' (Honneth 2009, 180). Honneth argues that while "the tight interlocking that once existed between 'intellectuality' and social criticism" has significantly loosened, this should not been seen as a negative development, but rather "the cultural byproduct of what can be described as the successful establishment of a democratic public sphere" (Honneth 2009, 182).

According to Honneth, interventions in the political public sphere, which aim at specific corrections of dominant interpretations or at advancing new perspectives on particular issues, must avoid recourse large-scale theoretical explanations. By contrast, explanatory theories are indispensable tools of social criticism: "For the greater the investment in sociological or historical explanation, the greater the danger of losing sight of the practical political demands of the addressees. If contemporary intellectuals must therefore practice a certain abstinence with regard to explanatory theories, social criticism, to the contrary, now as ever is fundamentally reliant on them. To be able to justify why accustomed practices or convictions are questionable as a whole, social criticism must offer a theoretical explanation that allows the development of an apparatus to be under-

21 (Honneth 1995, 71-91; Honneth 2007, 218-239). 
stood as the unintended consequence of a chain of intended circumstances or actions. As much as the theoretical contents may be distin-guished from one another, as manifold as the explanations may be, their task within social criticism is the same in all cases: they help show that we cannot endorse the institutional totality or form of life we practice everyday because it is the merely causal result of a developmental process that can be understood in its individual components" (Honneth 2009, 186).

Honneth emphasizes additional differences between social critique and the engagement of intellectuals in the public sphere. For example, while ethical exaggerations and one-sidedness might be permissible for social critics, intellectuals today have to maximize the neutrality of their worldviews, "since when possible they must seek agreement in the political public sphere. The limits on social criticism thus arise from what a public composed of highly mixed worldviews is prepared to understand; those the intellectual comes up against, however, are established by the liberal principles of a public sphere that reasons democratically. The intellectual must promote his opinion with artful arguments while respecting these principles, whereas the social critic can try to convince us that accustomed modes of practice are questionable by using an ethically laden theory" (Honneth 2009, 187).

In other words, social criticism is not, and should not be, subject to the same constraints imposed on public intellectuals because this would unduly restrict the critical potential of the former as Honneth rightly notes: "Nothing would be more detrimental to social criticism than making its revelation of questionable social practices depend on their prospects of political implementation. Social criticism does not aim at rapid success in the democratic exchange of opinions but at the distant effect of gradually growing doubt about whether given models of practice or schemas of needs are in fact appropriate (for us). It is paid in the coin not of momentary argumentative convincingness but in justified reorientation in future processes" (Honneth 2009, 188).

The relevance of Honneth's notion of task of social critics for contemporary democratic societies can be captured by Honneth's claim which is: "The success of their activity (social critics - L.D.) is not measured [...] by quickly convincing a quarrelsome, divided public but, rather, through the long-term reorientation of a public confident in prevailing ideas. What among intellectuals is a sense of proportion, a convincing argument, or recognizable engagement for a minority must be almost completely replaced for the social critic by the creative ability to give texts a disintegrating effect on social myths" (Honneth 2009, 189). So, we should aim at long-term social transformation by calling into question the ideals and values behind the prevailing social order thereby initiating a gradual shift in the 
normative orientation of society, a shift that cannot be understood as the aggregate or sum total of individual actions. ${ }^{22}$

\section{Conclusion}

The point of departure of this paper is an attempt to adequately reflect on sociocultural transformation. The text tries to describe a specific character of contemporary neoliberalist wave in the Visegrad-Four Countries, by which it is possible to find similarities to communist radicalism at the beginning of the second half on the $20^{\text {th }}$ Century. The core of those similarities consists in the beliefs, that the principles used from a neoliberal perspective are absolutely rational. However, the empirical experiences of the past 25 years show how problematic this belief is. The paper exemplifies these shortcomings of these beliefs with the problems of the Slovak educational system. Therefore, the second part of the article shortly considered three possible ways to better understand sociocultural transformations and suggest the pragmatist as the most productive one. The paper offers a short characterisation of the spirit of pragmatism in the work of Emil Višnovský and by Axel Honneth's description of the task of social critics today.

As a result, it can be pointed out, that the best way for the Visegrad-Four Countries for solving their problems in various spheres of society lies in a moderate understanding of sociocultural transformation. The lessons from the philosophy of pragmatism can teach them, how to reform their societies with a minimum of costs and a maximum of yield.

\section{References}

ARNASON, J. P. (2010): Dějinnost, nadcivilizace a modernita. Studie k Patočkově konceptu nadcivilizace [Historicity, Supercivilization and Modernity. Studies on Patočka's Concept of Supercivilization]. Praha: Togga.

DERANTY, J.-P. (2009): Beyond Communication. A Critical Study of Axel Honneth's Social Philosophy. Leiden - Boston: BRILL.

DEWEY, J. (1988): The Latter Works 1925-1953. Volume 13: 1938-1939.

Carbondale and Edwardsville: Southern Illinois University Press.

DINUŠ, P. (2010): Vyrovnávanie sa s minulost'ou. [Getting over the History] Bratislava: VEDA.

22 The last passage of my paper, which describes Axel Honneth's considerations about the task of social critics I also used in my dispute with Marina Čarnogurská's interpretation of Daoism. See (Dunaj 2015). 
DINUŠ, P. (2015): Politika bez masky. Príspevok $k$ politickému diskurzu na Slovensku po roku 1989. [Politics without a Mask. A Contribution to Political Discourse in Slovakia after 1989]. Bratislava: VEDA.

DUNAJ, L. (2015): Potentialities and Limitations of Marina Čarnogurská's Interpretation of the Daoist Understanding of Social Reality. In: Journal of Sino-Western Communications 2015, Volume VII, Issue 1.

HONNETH, A. (1995): The Struggle for Recognition. The Moral Grammar of Social Conflicts. Cambridge: The MIT Press.

HONNETH, A. (2007): Disrespect. The Normative Foundations of Critical Theory. Cambridge - Malden: Polity Press.

HONNETH, A. (2009): Pathologies of Reason. On the Legacy of Critical Theory. New York: Columbia University Press.

HVORECKÝ, J. (2015): Testament vedca. Kolaps školstva a cesta $k$ oživeniu. [Scholar's Testament. The Collapse of Education and the Way to Recovery]. Bratislava: Premedia.

JOAS, H. (1993): Pragmatism and Social Theory. Chicago: The University of Chicago Press.

JULLIEN, F. (2011): The Silent Transformations. Seagull Books.

KÖGLER, H.-H. (2006): Kultura, kritika, dialog. Prague: FILOSOFIA (Orig.: Kögler, H.-H., A Critical Hermeneutics of Subjectivity: Cultural Studies as Critical Social Theory).

KRAPFL, J. (2013): Revolution with a Human Face: Politics, Culture, and Community in Czechoslovakia, 1989-1992. Ithaca: Cornell University Press.

LIESSMANN, K. P. (2006): Theorie der Unbildung. Die Irrtümer der Wissensgesellschaft. Wien: Paul Zsolnay Verlag.

NOVOSÁD, F. (2004): Alchýmia dejín. [The Alchemy of History].Bratislava: Iris.

PATOČKA, J. (1996): Nadcivilizace a její vnitřní konflikt. [Supercivilization and its Inner Conflict]. In: Sebrané spisy V. 1, Péče o duši I. [Collected Works]. Praha: Oikoymenh, 243-302.

ROETZ, H. (2011): Die Chinawissenschaften und die chinesischen Dissidenten. Wer betreibt die „Komplizenschaft mit der Macht"? In: MOLL-MURATA, Ch. ROETZ, H. (eds.): Dissens in China. Bochumer Jahrbuch zur Ostasienforschung Bochum Yearbook of East Asian Studies, 47-79.

SÝKORA (2014): O súčasnom systéme hodnotenia a financovania vedeckovýskumnej činnosti na slovenských verejných vysokých školách. [The current system of evaluation and financing of scientific research activities at the Slovak public universities]. In: (Višňovský, 2014b). 90-115. 
TÍŽIK, M. (2014): O akademickom diskurze a jazyku [On Academic Discourse and Language]. In: (Višňovský, 2014b), 167-186.

VIŠŇOVSKÝ, E. (2009): Človek ako Homo agens [Man as Homo Agens]. Bratislava: IRIS.

VIŠŇOVSKÝ, E. (2014a): Nové štúdie o pragmatizme a neopragmatizme. [New Studies on Pragmatism and Neopragmatism]. Bratislava: VEDA.

VIŠŇOVSKÝ, E. (ed.) (2014b): Univerzita, spoločnost', filozofia: realita versus hodnoty. [University, Society, Philosophy: the Reality vs. Values]. Bratislava: Iris.

\section{Lubomír Dunaj, Ph. D.}

University of Prešov

Center of Competencies and Lifelong learning

Ul. 17. novembra 15

08001 Prešov

Slovak Republic

lubomir.dunaj@gmail.com 